\title{
Firm Performance and Market Behavior during First Wave of COVID-19 in Egypt: Panel Data Analysis
}

\author{
May Elewa \\ Assistant Professor Accounting, School of Business Administration \\ Ahram Canadian University - Giza Egypt \\ Shwikar Nagy \\ Assistant Professor of Accounting, Faculty of Economics and Management \\ October $6^{\text {th }}$ University - Giza, Egypt
}

Received: May 5, $2021 \quad$ Accepted: July 13, $2021 \quad$ Published: December 1, 2021

doi:10.5296/ajfa.v13i2.18846 URL: https://doi.org/10.5296/ajfa.v13i2.18846

\begin{abstract}
The purpose of this paper is to identify the impact of market capital MC and net profit NP on stock price SP and trade volume (TV) in the developing Egyptian business context. This study collects data from 29 non-financial organizations registered on the EGX 30 during the 6 month, $1 / 1 / 2020$ to 30/6/2020, lockdown in Egypt due to the first wave of COVID-19. Data for the monthly confirmed cases and death cases of COVID-19 are collected for the 6 months of the study and compared to the monthly records of closing prices and trade volume in Egyptian pounds EGP. The study population represents 174 firm year observations. The firms studied operate in cash, have annual financial reports during the period $1 / 1$ to $31 / 12$, obtain complete financial data, and have not been eliminated all throughout the study. In this work the pooled model, the fixed effects model, and the random effects model are used. SPSS is applied to achieve the required statistical analysis. The study is a panel data analysis. Outcomes demonstrate existing substantial effects between market capital MC and stock price SP during the first wave of COVID-19. However, no significant effect is evident of the market capital MC and net profit NP with the trade volume TV during the first wave of this pandemic. This literature is advantageous for external and internal stakeholders and regulatory bodies. The study is a modest contribution that may help boost the business processes to reach better financial performance in times of unexpected catastrophes.
\end{abstract}

Keywords: market capital, net profit, stock price, trade volume, COVID-19, Egypt 


\section{Introduction}

An increasing public and media awareness has come to being of the efforts made by corporations in the Egyptian culture. (Abdelshahid, 2003) discusses that the Egyptian stock exchange is ready for the age of globalization. The stock market is an instrument that offers investors the opportunities to trade with an assortment of financial assets and collect a return on them. Even though stock prices are unclear of the upcoming worth of the firms, the general belief remains that information is revealed in the alteration of existing stock prices. Investors consider the behavior of the stock market when making investment decisions.

Egypt is found in the Middle East which is considered a politically disturbed and unsound area. Regardless of these circumstances, Egypt has showed continuous and swift economic progress in parallel to other developing economies (Elsayed and Hoque, 2010; and Dahawy and Samaha, 2010). According to (Samaha and Dahawy, 2010), Egypt is greatly progressing in economic reform, refining investment environment and drawing local, regional and foreign direct investments. Furthermore, Egypt is going through a privatization plan to several of its public organizations. Egypt is a growing country that is moving to being a market economy.

However, the COVID-19 virus has transported great social anguish and detrimental economic disruption (OECD, 2020). Never the less, in the latest forecast from the IMF`s World Economic Outlook, Egypt is expected to be the only country in the MENA region to witness positive economic growth in 2020, estimated at 1.95\%. Thus, the Egyptian model is considered as an inspiring model to be followed in the MENA region. Estimates from the Egyptian Center for Economic Studies indicate that the effects of Covid-19 on the Egyptian economy are likely to continue till June 2021 due to declining travel and tourism, lower domestic consumption, capital outflows, and reduced remittances. Weaker global trade is also expected to reduce Egypt 's exports and earnings from the Suez Canal. Foreign direct investment is also expected to decrease and only gradually increase to the pre-crisis levels by June 2021 .

(Dahawy, 2009) finds that the qualities of financial statement disclosure from firms registered in the Egyptian stock exchange are influenced by the exceedingly secretive Egyptian culture. We confirm this argument through the data collected for the 6 months of 1/1/2020 to 30/6/2020 lock down period in Egypt for 29 non-financial institutions listed in the EGX 30. The public data issued by the Ministry of Health and Population of Egypt show that from January 2020 till June 2020 monthly confirmed cases of COVID-19 recorded were January 0 cases, February 2 cases, March 710 cases, April 5537 cases, May 24985 cases, June 68311 cases. The monthly death cases from COVID-19 recorded were January 0 cases, February 0 cases, March 46 cases, April 392 cases, May 959 cases, June 2953 cases. According to the public data issued on MUBASHR MISR the monthly recorded closing prices were in Egyptian pounds EGP January 13918.84, February 13008.94, March 9593.94, April 10554.04, May 10220.14, and June 10764.59. The monthly recorded trade volume were in Egyptian pounds EGP January 1433193887, February 1891092410, March 3643681016, April 4185316058, May 2059843502, and June 232406248. After carefully observing these numbers we notice; a sharp monthly increase in the COVID-19 confirmed cases, a sharp monthly increase in the COVID19 death cases, a plunge in the monthly recorded closing prices, and an increase from January 
1433193887 to April 4185316058 where the trade volume reached its peak and then there was a sharp decrease from May 2059843502 and June 232406248 in the trade volume.

This study is limited to the EGX 30 non-financial institutions only. This study analyzes the relationship that exists among the market capital MC, net profit NP, stock price SP, and trade volume TV. This study does not go in depth as to whether or not COVID-19 confirmed cases and death cases actually have a direct relation with market capital MC, net profit NP, stock price SP, and trade volume TV. Till now Egypt has gone through two waves of the COVID-19 and the third wave is on the way. This study makes its evaluation during the first wave only. It focuses on the lockdown period.

To our knowledge, no previous study has been made using these variables under this condition in the Egyptian business environment. In addition, related literature seems to be rare. This study tries to reduce this research gap. The aim is to search for those variables that represent firm performance that will increase the stock price and trade volume in the Egyptian non-financial publicly listed firms during this pandemic.

The rest of this paper continues along these lines; the second part presents the literature review and hypotheses development, the third part explains the research methodology, and the fourth part reveals the conclusion and proposes future studies.

\section{Literature Review and Hypotheses Development}

Here, is a presentation of some of the work of other researchers and their observations and their findings relating to the subject matter. There are various concepts that have emerged that try to clarify why organizations come to being and the rationale for the variances in their establishment and performance. Some of these are the economies of scale theory, agency theory, shareholder theory, and stewardship theory.

The economy of scale theory explains how large firm size is of greater influence over small firm size. (Padron et. al., 2005) agrees with the idea that the firm profitability and firm size and are associated in line with the economies of scale theory. This perspective approves that largesize firms have the ability to: compete with their counterparts, negotiate with suppliers and customers, create and sustain strategic expansion, keep higher prices than the competitive level. (Schmitt and $\mathrm{Yu}, 2001$ ) demonstrates that a rise in the range of economies of scale promotes the size of intra-industry trade and the share of trade in total production.

According to (Eisenhardt, 1989) agency theory defines the link between two groups, the agentmanager and the principal. This study also points out that the principal-manager connection defines any type of relationship where work is passed on from a principal to a manager, irrespective of actual position. Both (Davis et al., 1997 and Eisenhardt, 1989) imply that the agency theory proposes that managers will select devious selfish conduct instead of conduct meant for making the most of the principal's interest. (Davis et. al., 1997; Eisenhardt, 1989; Jensen and Meckling, 1976; Ross, 1973) confirm the agency theory postulates agents will act speculatively because they are selfish. Consequently, the principal endorses tools to reduce losses to their own convenience. (Kultys, 2016) suggest the agency theory postulates selfishness and the quest of one's own benefits. (Teixeira, 2017) infers that the agency theory 
addresses potential conflicts between shareholders and managers.

(Mahoney, 2012) suggests that considering shareholders as the only criteria is a weak description of the actual relationships among a firm's various stakeholders. Stakeholder theory begins with the assumption that values are necessarily and explicitly a part of doing business. It asks managers to articulate the shared sense of the value they create, and what brings its core stakeholders together. It also pushes managers to be clear about how they want to do business, specifically what kinds of relationships they want and need to create with their stakeholders to deliver on their purpose. (Freeman et. al., 2010) support stakeholder theory as a means of facilitating understanding of the complexities of today's business challenges as the problem of understanding how value is created and traded, the problem of connecting ethics and capitalism, and the problem of helping managers think about management. Establishing good relations with primary stakeholders can lead to higher financial returns. Fair and balanced stakeholder's outlook ends up with long term shareholders maximization significance (Elena, 2007; Gioia, 1999; Sternberg, 1994; Cooper, 1996; Kaplan and Norton, 1992). (Rampling, 2012) argues that there is much benefit and correlation by reordering executive focus and remuneration incentives away from the agency theory model to a managerial model of stakeholder theory.

(Hernandez, 2008 and Zahra et. al., 2008) indicate that the stewardship theory relates managers to stewards with behavior that is built on a fundamental aspiration to work for the firm thus indeed supporting the principal's interests. (Davis et. al., 1997; and Donaldson and Davis, 1991) point out that the stewardship theory relates to the work bond concerning two individuals, the principal (owner) and the steward (manager). The studies examine this bond from a social and a physical viewpoint. (Zahra et. al., 2009 and Davis et. al., 1997) argue that the stewardship theory proposes that managers will act in a pro-social manner intended for the benefit of the owner hence the organization. In the steward-principle relationship, the steward places the interests of the principal before selfish benefits (Davis et. al., 2010; Zahra et. al., 2009; Corbetta and Salvato, 2004; Davis et. al., 1997). According to (Davis et. al., 1997) the principal generates an organizational structure where stewardship behaviors can mature. Thus, a stewardship arrangement considered supportive and collectivistic, causing rewards for the organization.

(Madison et. al., 2016) argues that agency and stewardship theories are opposite theories. However, they deal with the identical phenomena of the individual-level activities and firmlevel governance tools that forecast organizational consequences. (Davis et. al., 1997) explains that stewardship theory is like the agency theory because it describes the relationship between the principal and the steward-manager from an authoritative and a social outlook. Both the stewardship and the agency theories propose opposing suppositions and expectations for firm performance (Cruz et. al., 2010; Chrisman et. al., 2007; Wasserman, 2006; and Tosi et. al., 2003). Stewardship theory may be opposing or corresponding to the agency theory depending on the status quo.

(Zaigham et. al., 2019) test the influence of stock price behavior on firm investment and the counter impact of variations in investment expenditures on stock price behavior. The study uses the random effects model on the data collected from manufacturing firms registered on the 
Shanghai Stock Exchange and the Shenzhen Stock Exchange China throughout 2002 - 2016. The sample covers 398 firms. Findings show the influence of stock price on investment expenditures is way more than that of investment expenditures on stock price. In addition, there is a statistically significant negative association between stock price and investment expenditures.

(Hanuman and Shrimal, 2014) examines literature in line with the relationship between firm financial performance and its market capitalization and leading to the conclusion that other studies have established a positive relationship.

(Handayani, 2018) determine the effect of market value, profitability, solvency, activity and liquidity to the stock price of 23 institutions in consumer goods manufacturing sectors registered on the Indonesia Stock Exchange Indonesia during 2014-2016. The independent variables are Debt to Equity Ratio (DER), Price Earnings Ratio (PER), Total Assets Turnover (TATO), Current Ratio (CR), Return on Equity (ROE), and Return on Assets (ROA). The dependent variable is stock price. The findings concluded that ROE and TATO affect the stock prices of companies manufacturing consumer goods, while the variables PER, DER, CR, and ROA do not affect the stock prices of companies manufacturing consumer goods.

(Puspitaningtyas, 2017) determines if financial performance is actually reflected in stock prices. Financial performance is measured using liquidity, profitability, growth, and market valuation. The population of this study is a non-banking company registered in the Indonesia Stock Exchange Indonesia and incorporated in LQ45 Index during 2011- 2016. Multiple linear regression analysis is used. Findings showed that only market valuation variables significantly influence stock prices, while, liquidity, profitability, and growth have no effect on stock prices.

(Asmirantho and Somantri, 2017) determine the effect of liquidity, solvency, activity, profitability and stock price with Debt to Equity Ratio (DER), Return on Equity (ROE), Total Assets Turnover (TATO), Earnings per Share (EPS), and Current Ratio (CR) for the pharmaceutical entities registered in Indonesia Stock Exchange Indonesia during 2012-2016. Inferential statistics and regression analysis of panel data is used. The results show EPS has partial significant effect on stock price, while CR, ROE, DER, and TATO have no significant effect on stock price.

(Chessar, 2015) analyze the relation between market capitalization and stock price volatility in the Nairobi Securities Exchange Kenya throughout 2010-2014. The statistical regression analysis is used. A descriptive survey design using quantitative data from secondary sources was applied. Findings show the most significant factor that affected the stock market volatility of the listed firms was market capitalization followed by liquidity.

(Chashmi and Fadaee, 2016) investigates the impact of the financial performance represented by (earnings per share EPS, return on equity ROE, and return on assets ROA) and growth opportunities on success or failure of 115 registered companies in the Tehran Stock Exchange Iran during 2006-2012. Measures of financial performance and growth opportunities are the independent variables and success or failure are the dependent variables. Pearson correlation coefficient and multiple regressions were used. The findings showed a significant relationship 
between EPS and ROA with success or failure, but there is no significant relationship between ROE and success or failure, and there is no significant relationship between growth opportunities and success or failure.

(Nassirzadeh et. al., 2015) evaluate the effectiveness of liquidity ratios, profitability ratios, efficiency ratios, debt ratios, and stock market ratios on trade volume of 67 institutions registered in the Tehran Stock Exchange Iran for the duration of 2010-2014. Hierarchical Multiple Regression and a general regression were used. The outcomes specify that performance and liquidity ratios are considerably associated to trade volume and the most significant is the working capital.

(Shawer and Al-Ajlouni, 2018) explore the relationship between the profitability measured by return on investment ROI, return on equity ROE and net profit NP and stock market prices of the Petrochemical Industry Firms in Saudi Arabia during the period 2008-2015. Multiple regression analysis is employed. The study confirms that the stock prices of petrochemical companies registered in the Saudi Stock Market does not reflect its profit performance.

(Odularu, 2009) analyses the impact of companies' shares on their performance, using one of the largest confectionary companies in Nigeria as a case study. The study analyses the correlation concerning the sales of shares and the progression of the company. Ordinary Least Square (OLS) analytical technique is used. The company's annual data for 20 years is evaluated. Findings indicate profit after tax, dividends, and turnovers have positive and statistically robust implication on the fluctuations in the company's operations and the value of its market capitalization.

(Elewa, 2016) examines the relationship between the independent variable firm performance proxied by (return on equity ROE, property plant and equipment turnover ppet, return on assets ROA, equity ratio ER, earnings per share EPS, non-discretionary accruals NDA) and the dependent variable trade volume. The sample of the study consists of 62 nonfinancial institutions from the EGX100 listed on the Egyptian stock exchange Egypt in 2007-2014, which is equivalent to 496 firm year observations. Multiple regression analysis was used. Findings indicate that no relation was supported between any of the variables that represent the firm performance (earnings per share EPS, return on assets ROA, property plant and equipment turnover ppet, return on equity ROE, equity ratio ER, non-discretionary accruals NDA) and the trade volume. This is a signal that maybe the relationship is limited to none between (ROA, EPS, ROE, ppet, ER, NDA) and the trade volume despite, stock prices and trade volumes go hand in hand in reality when evaluating firm performance.

(Dahawy and Samaha, 2012) state that in spite of the difficulty of getting hold of annual reports by the general public and the lack of reliance on information, greater number of users perceive these reports to be the most essential resources of firm information. Egyptian users depend more on annual report information than on advice from stock holders and friends or on tips and rumors.

(Chandrapala, 2011) examines the relationship between trade volume and stock returns. The sample of the study consists of 266 stocks traded at the Colombo Stock Exchange (CSE) Sri 
Lanka during 2000-2008. This study follows the conventional methodology used by Jagadeesh and Titman (Jagadeesh and Titman, 1993). Findings revealed that stock returns are positively related to the change in past trade volume.

(El-Ansary and Atuea, 2012) examines the relationship between trade volume and stock return. The study sample consists of 26 out of 30 companies listed in EGX 30 Index Egypt. The study covers the period from $1 / 7 / 2001$ to $21 / 3 / 2010$. The data consists of daily numbers of traded stocks, numbers of outstanding stocks, daily numbers of transactions and the corresponding daily closing price for each stock. The Pearson Correlation Coefficient, the General Autoregressive Conditional Hetroskedasticity GARCH $(1,1)$ model, and the Granger Causality Test were applied. Findings show a simultaneous relationship between trade volume and stock return.

(Girard and Omran, 2009) tests the relations of volume and volatility. The sample consists of returns of 79 listed institutions at the Cairo and Alexandria Stock Exchange (CASE) Egypt during January 1998 to May 2005. The General Autoregressive Conditional Hetroskedasticity GARCH $(1,1)$ model is used. Some results are evident. First, information direction and size have an unimportant effect on conditional volatility so the existence of imaginary bubbles and noise trading is assumed. Second, volatility persistence decreases when volume is broken down even more into its unexpected and expected components. Last but not least, projected information shocks have a negative influence on the volatility of return that suggests information distribution and trade efficiency have developed. This in-turn reinsures foreign investors and boosts the reform momentum.

(Joher, et. al., 2005) examines the volatility characteristics of Kuala Lumpur Stock Exchanges Malaysia by considering mixing variable (volume) as innovation. This study presents a comprehensive analysis of the distributional and time series properties of returns. The GARCH $(1,1)$ model is used. Findings indicate that current volatility can be clarified by past volatility that is likely to continue over time. The return volatility is best explained by a $\operatorname{GARCH}(1,1)$ specification. This study considers volume as an additional explanatory variable contained by the $\operatorname{GARCH}(1,1)$ model to examine if it can actually capture $\operatorname{GARCH}(1,1)$ effects. Results show that the persistence in volatility rests in the return series even when volume is incorporated in the model as an explanatory variable. This finding holds for simultaneous volume when it is comprised in the variance equation.

(Habib, 2011) investigates the joint dynamics of stock returns and trade volume in the Egyptian Securities Exchange (ESE) Egypt during the period 1998-2005. Findings establish several regularities about the role of trade volume in predicting the volatility of return. First, the lagged stock trade volume has an insignificant role to play in forecasting the future return volatility. Second, there is no relation between volume and first autocorrelation of stock return. Third, the Granger causality tests indicate a bidirectional causal relation between volume and volatility. Specifically, any change in return volatility leads to a change in trade volume and vice versa. However no such inference can be made about the causal relation between return and volume.

(Farag, 2011) examines the link concerning stock returns and trade volume of small and medium-sized enterprises in the Nile Stock Exchange Egypt. Data consists of daily stock price 
and trade volume for 12 firms. The investigation covers the period from the first day of trade 03 June 2010 to 01 June 2011. The findings suggest that the stock returns are influenced by the trade volume and vice versa.

(Abdelzaher, 2019) evaluates the consequences of the Egyptian revolution on the stock performance in the Egyptian stock market throughout 2010-2012 by evaluating its influence on closing price, market return fluctuation, and trade volume. These variables are examined before and after the Egyptian revolution that happened on January $25^{\text {th }}$. The co-integrating equation model, the descriptive statistics group unit root test, the ARCH model, and the GARCH $(1,1)$ model, are applied. The sample contains 30 institutions registered on the EGX30 index Egypt. The independent variable is the Egyptian revolution that happened on January $25^{\text {th }}$. The dependent variables are the trade volume, the fluctuation of returns, and the closing prices. Findings indicate; the Egyptian revolution had a significant negative impact on the closing prices, while it had a significant positive impact on the return fluctuation. The revolution had no significant impact on the trade volume. However, the trade volume decreased before, during, and after the January $25^{\text {th }}$ Egyptian revolution.

(Sun, 2003) discusses how volume and price move together and how unusual volume can be a predictive measure of future price changes.

(Gul, 2009) investigates the link regarding volume and price changes of individual stocks on a given day. An empirical analysis is made to evaluate the link concerning performance of the stock exchange index and trade volume. Data for 92 successive days are gathered from June 18, 2007 to October 31, 2007. This data is gathered from the Karachi Stock Exchange Pakistan website. The data is form the KSE 100 index and of the measures of volume. Descriptive statistics are used. Findings indicate that; a similar relationship exists, a significantly positive correlation exists, and the price-volume relationship occurs.

(Alber, 2020) states that the COVID-19 spread is not considered "an event", as it does not have proper dated information content for use to determine the event window in terms of event study methodology. In addition, the spread of this virus is still going on from the first wave to the second wave and now on the third wave with rapid transformation, making it difficult to identify the event period. So, (Alber, 2020) pursues to examine the effects of COVID-19 outbreak on the European stock markets. The study measures the COVID-19 spread in terms of cumulative cases, new cases, cumulative deaths and new deaths, while abnormal return of stock market is measured according to the market model. (Alber, 2020) examines the stock markets of France, Italy, Germany, Belgium, Spain, UK, and Netherlands, on an everyday basis throughout the Febreuary15, 2020 to May 24, 2020. A vigorous check has been conducted on 273 stocks during the study period of (100 days). Findings prove that stock markets have reacted negatively to the COVID-19 spread during the first and second period. Findings don't support any negative effects during the third and fourth periods. Starting from the fifth period, stock markets seem to be influenced negatively by "Relative Cumulative COVID-19 Deaths" (RCCD). According to results of investigations made on the country effect, the stock markets of Germany, Netherlands and UK have been affected by the COVID-19 spread during the second period. However, these results for Belgium, France, Italy and Spain, have been 
supported during the fourth period.

The above literature review portrays some of the different studies made on different business environments of different countries (China, Indonesia, Kenya, Iran, Nigeria, Saudi Arabia, Sri Lanka, France, Belgium, Italy, Germany, Spain, UK, and Netherlands) to identify different variables that have an impact on the firm stock price and trade volume. This study then focuses on trying to identify variables that might have a positive significant impact on the firm stock price and trade volume in the Egyptian business environment during the first wave of COVID19.

Thus, from the above literature review, the following question arises:

Q- Do market capital MC and net profit NP have an effect on firm's stock price SP and trade volume TV in the Egyptian business environment during the first wave of COVID-19?

From here, we develop the following hypotheses:

H1: market capital has a significant impact on stock price and trade volume during the first wave of COVID-19.

$\mathrm{H} 2$ : net profit has a significant impact on stock price and trade volume during the first wave of COVID-19.

\section{Research Methodology}

This study examines the link concerning the market capital MC, net profit NP, stock price SP and trade volume TV of the non-financial institutions listed in the EGX30 during the first wave of COVID-19. The public data issued by the Ministry of Health and Population of Egypt show that from January 2020 till June 2020 monthly confirmed COVID-19 cases recorded were January 0 cases, February 2 cases, March 710 cases, April 5537 cases, May 24985 cases, June 68311 cases. The monthly death cases from COVID-19 recorded were January 0 cases, February 0 cases, March 46 cases, April 392 cases, May 959 cases, June 2953 cases. According to the public data issued on MUBASHR MISR the monthly recorded closing prices were in Egyptian pounds EGP January 13918.84, February 13008.94, March 9593.94, April 10554.04, May 10220.14, and June 10764.59. The monthly recorded trade volume TV were in Egyptian pounds EGP January 1433193887, February 1891092410, March 3643681016, April 4185316058, May 2059843502, and June 232406248. There was an increase from January 1433193887 to April 4185316058 where the trade volume TV reached its peak. There was a sharp decrease from May 2059843502 and June 232406248. These numbers imply; a sharp monthly increase in the COVID-19 confirmed cases, a sharp monthly increase in the COVID19 death cases, a plunge in the monthly recorded closing prices, and an increase from January 1433193887 to April 4185316058 where the trade volume TV reached its peak and then there was a sharp decrease from May 2059843502 and June 232406248 in the trade volume TV. Further investigation is needed to identify the reasons behind the increase of trade volume during the first wave of COVID-19 according to the recorded data.

It is worth noting that MUBASHR MISR is a website that covers financial and stock markets $\&$ provides latest prices $\&$ values for local and global exchanges in addition to company initial 
public offering IPO, which is the process by which a private company can go public by sale of its stocks to the general public.

The data for the study is collected for the period from 1/1/2020 to 30/6/2020 that represents the period of quarantine in Egypt as indicated from the Egyptian presidential rulings. The data collected are for 28 non-financial institutions listed in the EGX30 during 6 months equivalent to 168 firm year observations. These institutions operate in cash, have not been eliminated from the index throughout the study, have complete data, use the Egyptian pounds EGP to record in their financial statements, financial period starts $1 / 1$ and ends $31 / 12$. These 28 institutions are (Porto group, DICE, GB auto, Egyptian chemicals-kema, Pioneers Holding, Ezz Steel, Citadel Capital, ELSWEDY ELECTRIC, Palm Hills Development, Eastern Company, T M G Holding, Heliopolis Housing, Telecom Egypt, Cairo For Investment, Juhayna Food Industries, Sidi Kerir Petrochemicals, Orascom Investment, Six of October Development, Medinet Nasr Housing, Cleopatra Hospital, Egyptian Financial Group-HERMES, Orascom Development, Emaar Misr for Development, Orascom Construction PLC, CI Capital Holding, Alexandria Mineral Oils, Ibnsina Pharma, Egyptian for Tourism Oriental Weavers)

The market capital MC and the net profit NP are the independent variables, while the stock price SP and trade volume TV are the dependent variables.

\section{Empirical Results and Findings}

The study applied the pooled regression, the fixed effect, and the random effect techniques with the panel data analysis based on the following equation:

$$
y_{i t}=\alpha_{o i}+\beta_{i t} X_{i t}+E_{i t}
$$

$y_{i t}$ The dependent variable, attributed to $\mathrm{i}$ units, over the period $\mathrm{t}$

$\alpha_{\mathrm{oi}}$ : Represent the fixed term for the sample i

$\beta_{\mathrm{it}} \mathrm{X}_{\mathrm{it}}$ : Independent variable and its slope

$\mathrm{E}_{\mathrm{it}}$ : random error

The subsequent three models were employed to analyze the available panel data:

1- Pooled model

2- Fixed Effects Model

3- Random Effects Model

To indicate which model most suitably signifies the influence of the independent variables (MC and NP) on the dependent variable Stock Price (SP) or Trade Volume (TV), the following five steps were applied:

1- The Pooled Model

2- $\quad$ The Fixed Effect Model 
3- The results of the Pooled Model and the Fixed Effect Model were compared using the FTest

\section{4- The Random Effect Model}

5- The results of the Random Effects Model and the Fixed Effect Model were compared using the Hausman Test to verify the appropriate model for use.

The analysis was made by using the five steps twice:

First: when the dependent variable is represented by the stock price (SP) and the independent variables are represented by the MC and NP.

Second: when the dependent variable is represented by the trade volume (TV) and the independent variables are represented by the MC and NP.

Table 1. results of the pooled model of market capital and net profit jointly on stock price.

\begin{tabular}{|c|c|c|}
\hline Variable & Coefficient & Prob. \\
\hline $\mathrm{MC}$ & 0.422764 & 0.0001 \\
\hline $\mathrm{NP}$ & 1.685900 & 0.0483 \\
\hline
\end{tabular}

\begin{tabular}{|l|l|}
\hline Adjusted R-squared & 0.447415 \\
\hline F-statistic & 73.06131 \\
\hline Prob(F-statistic) & 0.000000 \\
\hline
\end{tabular}

Source: SPSS output program

According to table 1 presented above the F-test is used to evaluate the significance of the model, or the significance of the independent variables market capital MC and net profit NP jointly $(p=0.000000)$. If the $p$-value of F-statistics is less than 0.05 , the model is significant. If the $\mathrm{p}$-value of F-statistics is higher than 0.05 , the model is considered insignificant. According to the results of the pooled model, market capital $\mathrm{MC}$ and net profit $\mathrm{NP}(\mathrm{p}<0.05)$ where the $\mathrm{p}$-value for F-statistics $(0.000000)$ is less than 0.05 . This implies the whole model is significant.

The Adjusted R-square has a value of $44.7 \%$, which means that the independent variables are only able to explain less than or almost half of the changes in the stock price SP.

The t-test is utilized to test the significance of each independent variable market capital MC $(\mathrm{p}=0.0001)$ and net profit NP ( $\mathrm{p}=0.0483)$ individually. If the $\mathrm{p}$-value of $\mathrm{t}$-test is less than 0.05 , then the independent variable has a significant effect on the stock price SP. If the p-value of $t$ test is higher than 0.05 , then the independent variable has an insignificant effect on the stock price SP. According to the results, both the independent variables market capital $\mathrm{MC}(\mathrm{p}<0.05)$ and net profit NP $(\mathrm{p}<0.05)$ have a significant effect on stock prices SP.

The coefficient of market capital MC is 0.42 that means for every increase in the market capital $\mathrm{MC}$ by 1 billion dollars, the stock price SP increase -on average- by $\$ 0.42$, assuming the net profits are fixed. In addition, the coefficient of net profit NP is 1.69 that means that for each increase in the net profits by 1 billion dollars, the stock price SP increase -on average- by $\$ 1.69$, 
assuming the market capital is fixed.

Table 2.fixed effect model of market capital and net profit on stock price

\begin{tabular}{|l|l|l|}
\hline Variable & Coefficient & Prob. \\
\hline MC & 0.772085 & 0.0000 \\
\hline NP & 0.120755 & 0.7551 \\
\hline
\end{tabular}

\begin{tabular}{|l|l|}
\hline Adjusted R-squared & 0.974834 \\
\hline Prob (F-statistic) & 0.000000 \\
\hline
\end{tabular}

Source: SPSS output program

According to table 2 presented above the F-test is used to evaluate the significance of the model, or the significance of all independent variables market capital MC and net profit NP jointly (0.000000). If the p-value of F-statistics is less than 0.05, the model is significant. If it is higher than 0.05 , the model is considered insignificant. According to the results of the fixed effect model, market capital MC and net profit NP $(\mathrm{p}<0.05)$ where the $\mathrm{p}$-value for F-statistics $(0.000000)$ is less than 0.05 . Results imply the whole model is significant.

The Adjusted R-square is $97.4 \%$, which means that the independent variables are able to explain the changes in the stock price SP almost completely.

The t-test is conducted to test the significance of each independent variable market capital MC (0.0000) and net profit NP (0.7551) individually. If the p-value of t-test is less than 0.05 , then the independent variable has a significant effect on the stock price SP. If the p-value of t-test is higher than 0.05, then the independent variable has an insignificant effect on the stock price SP. According to the results, it is inferred that only market capital MC $(0.0000)$ where $(\mathrm{p}<0.05)$ has a significant effect on stock prices SP, and net profit NP $(0.7551)$ where $(p>0.05)$ has an insignificant effect on stock prices SP.

The coefficient of market capital MC is 0.77 which means that for each increase in the market capital by 1 billion dollars, the stock price SP increase -on average- by $\$ 0.77$, assuming the net profits are fixed.

Table 3. F- test of market capital and net profit on stock price

\begin{tabular}{|l|l|}
\hline Effects Test & Prob. \\
\hline Cross-section Chi-square & 0.0000 \\
\hline \hline Prob(F-statistic) & 0.0000 \\
\hline
\end{tabular}

\section{Source: SPSS output program}

To test the significance of the fixed effects, and to determine whether to choose the pooled model or the fixed effects model, the redundant fixed effects test was conducted. Both models were estimated first, and then the redundant fixed effects likelihood ratio is performed.

Redundant fixed effects test hypothesizes that the fixed effects are redundant and insignificant. 


\section{Ml Macrothink}

Asian Journal of Finance \& Accounting

ISSN 1946-052X 2021, Vol. 13, No. 2

According to table 3 to examine the significance of these fixed effects, F- statistic $=(0.000000)$ and chi-square statistic $=(0.0000)$ are conducted. If the p-value of F-statistic or p-value of chisquare statistic is less than 0.05 , the fixed effects are significant. If it is higher than 0.05 , the fixed effects are insignificant and redundant.

According to the results, the p-value of F- statistic $=(0.000000)$ and chi-square statistic $=$ $(0.000000)$ where the F- statistic $\mathrm{p}<0.05$, and chi-square statistic $\mathrm{p}<0.05$ which strongly reject the hypothesis of redundant fixed effects test. In other words, the results indicate that the fixed effects are statistically significant. So, the Fixed Effect Model results are used.

Table 4. random effects model of market capital and net profit on stock price

\begin{tabular}{|l|r|r|}
\hline Variable & Coefficient & Prob. \\
\hline MC & 0.734591 & 0.0000 \\
\hline NP & 0.027956 & 0.9376 \\
\hline
\end{tabular}

\begin{tabular}{|l|l|}
\hline Adjusted R-squared & 0.474172 \\
\hline Prob(F-statistic) & 0.000000 \\
\hline
\end{tabular}

Source: SPSS output program

According to table 4 above the F-test is used to evaluate the significance of the model, or the significance of all independent variables market capital MC and net profit NP jointly $(0.000000)$. If the $\mathrm{p}$-value of F-statistics is less than 0.05 , the model is significant. If it is higher than 0.05 , the model is considered insignificant. According to the results of the random effects model, it is inferred F-statistics $\mathrm{p}<0.05$, which means that the whole model is significant.

The Adjusted R-square has a value of 0.474172 that is equivalent to $47.4 \%$, which means that the independent variables are only able to explain less than or almost half of the changes in the stock price SP.

The t-test is conducted to test the significance of each independent variable market capital MC (0.0000) and net profit NP (0.9376) individually. If the p-value of t-test is less than 0.05 , then the independent variable has a significant effect on the stock price SP. If the p-value of t-test is higher than 0.05 , then the independent variable has an insignificant effect on the stock price SP. According to the results, only $\mathrm{MC}(0.0000)$ has $\mathrm{p}<0.05$ that infers to a significant effect on stock prices.

The coefficient of market capital MC is of 0.73 , which means that for each increase in the market capital by 1 billion dollars, the stock price SP increase -on average- by $\$ 0.73$, assuming the net profits are fixed.

Table 5. hausman test of market capital and net profit on stock price

\begin{tabular}{|l|c|}
\hline Variable & Random \\
\hline MC & 0.734591 \\
\hline NP & 0.027956 \\
\hline Chi-Sq. Statistic & Prob. \\
\hline
\end{tabular}




\section{\begin{tabular}{l|r|}
3.238073 & 0.1981
\end{tabular}}

Source: SPSS output program

The study analysis can be performed by using the fixed effects regression model or random effects regression model. According to table 5 above the Hausman test is conducted through the measurement and the evaluation of the Chi-square statistic $(p=0.1981)$ to choose the most appropriate regression model. If the p-value of Chi-square statistic is higher than 0.05 , the hypothesis is accepted and the random effects model is used. If p-value is less than 0.05 , the hypothesis is rejected and the random effects model is not used. Instead, the fixed effects model will be used.

Based on the results of Hausman test, the Chi-square statistic $(p=0.1981)$ where $(p>0.05)$, which means that the random effects model is used.

After applying the above five steps when the dependent variable is represented by the stock price SP and the independent variables are represented by the market capital MC and net profit NP, findings suggest that the Random Effects Model most appropriately represent the impact of the independent variables (market capital MC and net profit NP) on the dependent variable Stock Price SP where only MC has a significant effect on stock prices with a coefficient of 0.73 . This means that for each increase in the market capital by 1 billion dollars, the stock price SP increase -on average- by $\$ 0.73$, assuming the net profits are fixed.

Table 6. pooled model of market capital and net profit on trade volume

\begin{tabular}{|l|l|}
\hline Variable & Prob. \\
\hline MC & 0.5315 \\
\hline NP & 0.6211 \\
\hline
\end{tabular}

\begin{tabular}{|l|l|}
\hline Adjusted R-squared & 0.018267 \\
\hline Prob(F-statistic) & 0.073039 \\
\hline
\end{tabular}

Source: SPSS output program

According to table 6 above, the F-test is used to evaluate the significance of the model, or the significance of the independent variables market capital MC and net profit NP jointly (0.073039). If the p-value of F-statistics is less than 0.05, the model is considered significant. If the p-value of F-statistics is higher than 0.05 , the model is considered insignificant.

According to the results of the pooled model, market capital MC and net profit NP (0.073039) shows that $(p>0.05)$ where the $p$-value for F-statistics $(0.073039)$ is higher than 0.05 . Results imply the whole model is insignificant.

The Adjusted R-square has a very low value (1.8\%), which means that the independent variables are almost completely not able to explain the changes in the trade volume TV.

The t-test is also conducted to test the significance of each independent variable market capital MC (0.5315) and net profit NP (0.6211) individually. If the p-value of t-test is less than 0.05 , 


\section{NI Macrothink}

Asian Journal of Finance \& Accounting

ISSN 1946-052X 2021, Vol. 13, No. 2

then the independent variable has a significant effect on the trade volume TV. If the p-value of t-test is higher than 0.05, then the independent variable has an insignificant effect on the trade volume TV. According to the results, the $\mathrm{p}$-value of both the independent variables market capital MC (0.5315) and net profit NP (0.6211) are higher than $0.05(\mathrm{p}>0.05)$. Results infer that both the independent variables market capital MC $(\mathrm{p}=0.5315)$ and net profit $\mathrm{NP}(\mathrm{p}=$ 0.6211 ) have an insignificant effect on trade volume.

Table 7. fixed effect model of market capital and net profit on trade volume

\begin{tabular}{|l|l|}
\hline Variable & Prob. \\
\hline MC & 0.2109 \\
\hline NP & 0.9127 \\
\hline
\end{tabular}

\begin{tabular}{|l|l|}
\hline Adjusted R-squared & 0.702170 \\
\hline Prob(F-statistic) & 0.000000 \\
\hline
\end{tabular}

Source: SPSS output program

According to table 7 above, the F-test is used to evaluate the significance of the model, or the significance of the independent variables of capital market MC and net profit NP jointly $(\mathrm{p}=$ 0.000000). If the p-value of F-statistics is less than 0.05 , the model is significant. If the $p$-value of F-statistics is higher than 0.05, the model is insignificant. According to the results of the fixed effect model, market capital MC and net profit NP $(\mathrm{p}<0.05)$ where the p-value for Fstatistics $(0.000000)$ is less than 0.05 . Results imply the whole model is significant.

The Adjusted R-square is (0.702170) equivalent to $70.2 \%$ which means that the independent variables are able to explain more than two-third the changes in the trade volume TV.

The t-test is conducted to test the significance of each independent variable of market capital $\mathrm{MC}(\mathrm{p}=0.2109)$ and net profit NP $(\mathrm{p}=0.9127)$ individually. If the $\mathrm{p}$-value of the $\mathrm{t}$-test is less than 0.05 , then the independent variable has a significant effect on the trade volume TV. If the $\mathrm{p}$-value of the t-test is higher than 0.05 , then the independent variable has an insignificant effect on the trade volume TV. According to the results, $M C(p=0.2109)$ shows $(p>0.05)$ and NP $(p$ $=0.9127)$ shows $(p>0.05)$. Results infer that each of the independent variable market capital $\mathrm{MC}$ and the independent variable net profit NP are individually insignificant. 
Table 8. F-test on market capital and net profit on trade volume

\begin{tabular}{|l|l|}
\hline Effects Test & Prob. \\
\hline Cross-section Chi-square & 0.0000 \\
\hline Prob(F-statistic) & 0.073039 \\
\hline
\end{tabular}

Source: SPSS output program

To test the significance of the fixed effects, and to determine whether to choose the pooled model or the fixed effects model, the redundant fixed effects test was conducted. Both models are first estimated, and then the redundant fixed effects likelihood ratio is applied.

The redundant fixed effects test hypothesizes that the fixed effects are redundant and insignificant. To examine the significance of these fixed effects, F- statistic and chi-square statistic are conducted. If the p-value of F-statistic or chi-square statistic is less than 0.05 , the fixed effects are significant. If the p-value of F-statistic or chi-square statistic is higher than (0.05), the fixed effects are insignificant and redundant. According to table 8 above, results show the p-value of F-statistic is (0.073039) and the p-value of chi-square statistic is (0.0000).

According to the results, F- statistic (0.073039) and chi-square statistic (0.0000) it is clear that $(\mathrm{p}<0.05)$, which strongly reject the hypothesis of redundant fixed effects test. In other words, the results indicate that the fixed effects are statistically significant. So, the Fixed Effect Model results are used.

Table 9. random effects model of market capital and net profit on trade volume

\begin{tabular}{|l|l|}
\hline Variable & Prob. \\
\hline MC & 0.1958 \\
\hline NP & 0.9329 \\
\hline
\end{tabular}

\begin{tabular}{|l|l|}
\hline Adjusted R-squared & 0.001419 \\
\hline Prob(F-statistic) & 0.326487 \\
\hline
\end{tabular}

Source: SPSS output program

In table 9 above, the F-test is used to evaluate the significance of the model ( $p=0.326487)$, or the significance of all independent variables market capital MC and net profit NP jointly $(p=0.326487)$. If the $p$-value of F-statistics is less than 0.05 , the model is significant. If the $p$ value of F-statistics is higher than 0.05 , the model is insignificant. According to the results of the random effects model it can be found that the $(p=0.326487)$ for the F-statistics is higher than 0.05 . Results suggest that the whole model is insignificant.

The Adjusted R-square is (0.001419), which means that the independent variables are not able to explain the changes in the trade volume TV completely.

The t-test is also conducted to test the significance of each independent variable of market capital MC ( $\mathrm{p}=0.1958)$ and net profit $\mathrm{NP}(\mathrm{p}=0.9329)$ individually. If the $\mathrm{p}$-value of the $\mathrm{t}$-test is less than 0.05 , then the independent variable has a significant effect on the trade volume TV. If the $\mathrm{p}$-value of the t-test is higher than 0.05 , then the independent variable has an insignificant 
effect on the trade volume TV. According to the results, the market capital MC $(p=0.1958)$ shows $(p>0.05)$ and the net profit NP $(p=0.9329)$ shows $(p>0.05)$. Results conclude both the independent variables are insignificant.

Table 10. hausman test of market capital and net profit on trade volume

\begin{tabular}{|c|c|}
\hline Test Summary & Prob. \\
\hline Cross-section random & 0.8218 \\
\hline
\end{tabular}

\begin{tabular}{|l|l|}
\hline \multicolumn{2}{|l|}{ Cross-section random effects test comparisons: } \\
\hline Variable & Random \\
\hline MC & -0.001681 \\
\hline NP & 0.000763 \\
\hline
\end{tabular}

Source: SPSS output program

To choose between the two regressions models fixed effects or random effects, the Hausman test is conducted.

Hausman test hypothesizes that the random effects model is preferred. It uses Chi-square statistic to examine this hypothesis. If the p-value of Chi-square statistic is higher than 0.05 , the hypothesis is accepted, so the random effects model is used. If p-value is less than 0.05 , the random effects model is not used. Instead, the fixed effects model will be used. Based on the results of Hausman test in table 10 above, the p-value of Chi-square statistic is found to be $(0.8218)$, that is $(\mathrm{p}>0.05)$, which means that the random effects model is preferred.

The dependent variable, represented by the trade volume TV and the independent variables, represented by the market capital MC and net profit NP have gone through the above five steps. Findings assume the Random Effects Model most appropriately represent the impact of the independent variables market capital MC (-0.001681) and net profit NP (0.000763) on the dependent variable Trade Volume TV where the effects of both independent variables on Trade Volume are insignificant.

\section{Conclusion and Future Studies}

This study seeks to detect the influence of the market capital MC and the net profit NP on the stock price SP and trade volume TV in the developing Egyptian business setting during the lockdown in Egypt due to the first wave of COVID-19. The study uses the pooled model, the fixed effects model, and the random effects model. Findings suggest only the market capital $\mathrm{MC}$ has a significant effect on stock prices SP and both independent variables market capital MC and the net profit NP have an insignificant effect on Trade Volume TV.

Consequently, we make some suggestions to help enhance the results of related future studies. Even though stock prices, in the Egyptian stock market, are unclear of the upcoming worth of the firms, the general belief remains that information is revealed in the alteration of existing stock prices. Also, investors consider the behavior of the stock market when making investment decisions. We suggest that tools other than the stock price and trade volume to be used by the investors for more accurate decision making. We suggest further investigation to be 
undertaken to find the reasons behind the increase of trade volume during the first wave of COVID-19 according to the recorded data.

The Egyptian regulatory environment is weak; therefore financial reporting quality is inclined to be determined by manager's incentives instead of the strength of the country's financial reporting standards. We suggest that the information that reaches the users is of accuracy, simplicity, transparence, and is issued on a timely basis.

This study is limited to the EGX 30 non-financial institutions only. This study does not go in depth as to whether or not COVID-19 confirmed cases and death cases actually have a direct relation with market capital MC, net profit NP, stock price SP, and trade volume TV. Till now Egypt has gone through two waves of the COVID-19 and the third wave is on the way. This study makes its evaluation during the first wave during the lockdown period only because there are a lot of lessons learned from this period that can be used to better face any future confrontations with this or any other catastrophe in the Egyptian business environment. Thus, further studies can be made taking into consideration listed financial institutions (banks and insurance companies) instead of the listed nonfinancial institutions. Investigations can be made during the second and third wave of COVID-19. Future studies can also be made using other tools as dependent variables other than the stock price and trade volume. Finally, we suggest further studies to be made to find possible ways to strengthen the Egyptian regulatory bodies to be more prepared to aiding the Egyptian business environment to better handle unexpected catastrophes.

\section{Acknowledgement}

We appreciate the invaluable work of Mr. Mohamed M. Youssef, on the statistical analysis which substantially improved the article. The data used in this paper is available and can be accessed from MUBASHER MISR website and the Egyptian Center for Economic Studies.

\section{References}

Abdelrhim, Elsayed, Mohamed \& Farouh. (2020). Investment Opportunities in the Time of (COVID-19) Spread: The Case of Cryptocurrencies and Metals Markets. Available at SSRN 3640333. http://dx.doi.org/10.2139/ssrn.3640333

Abdelrhim \& Elsayed. (2020). The Effect of COVID-19 Spread on Egyptian Stock Market Sectors. SSRN Electronic Journal. https://doi.org/10.2139/ssrn.3608734

Abdelshahid. (2003). Does Ownership Structure Affect Firm Value? Evidence From The Egyptian Stock Market. https://doi.org/10.2139/ssrn.378580

Abdelzaher \& Abdelzaher. (2019). Women on Boards and Firm Performance in Egypt: Post the Arab Spring. The Journal of Developing Areas, 53(1). https://doi.org/10.1353/jda.2019.0013

Aggrawa. (2014). INTERNATIONAL CONFERENCE ON Management of Globalized Business: Emerging Perspectives.

Alber. (2020). Finance in the Time of Coronavirus During 100 Days of Isolation: The Case of the European Stock Markets. SSRN 3631517. http://dx.doi.org/10.2139/ssrn.3631517 
Allam, Mohamed, \& Abdelrhim, (2020), The Effect of the COVID-19 Spread on Investor Trading Behavior on the Egyptian Stock Exchange. SSRN Electronic Journal. 10.2139/ssrn.3655202. http://dx.doi.org/10.2139/ssrn.3655202

Asmirantho \& Somantr. (2017). The Effect of Financial Performance on Stock Price at Pharmaceutical Sub-Sector Company Listed in Indonesia Stock Exchange. JIAFE (Jurnal Ilmiah Akuntansi Fakultas Ekonomi), 3(2), 94-107. https://doi.org/10.34204/jiafe.v3i2.778

Bayrakdaroglu, Mirgen \& Ezgi. (2017). Relationship Between Profitability Ratios and Stock Prices: An Empirical Analysis on BIST-100. Press Academia Procedia, 6(1), 1-10. https://doi.org/10.17261/Pressacademia.2017.737

Chasmi \& Fadaee. (2016). Impact of Financial Performance and Growth Opportunities on Success or failure of Companies: Evidence from Tehran Stock Exchange. Journal of Accounting and Marketing, Science and Research Branch, Islamic Azad University, Mazandaran, Iran, 5(2), 2-5. https://doi.org/10.4172/2168-9601.1000166

Chessar, M., \& Bellarmine, V. (2015). Effect of Firms' Market Capitalization On Stock Market Volatility of Companies Listed at The Nairobi Securities Exchange. A Research Project submitted for the degree of MBA, University of Nairobi. Retrieved from:business. uonbi. ac. ke.

Chrisman, Sharma \& Taggar. (2007). Family Influences on Firms: An Introduction. Journal of Business Research, 60(10), 1005-1011. https://doi.org/10.1016/j.jbusres.2007.02.016

Chrisman, Chua, Kellermanns \& Chang. (2007). Are Family Managers Agents or Stewards? An Exploratory Study in Privately Held Family Firms. Journal of Business research, 60(10), 1030-1038. https://doi.org/10.1016/j.jbusres.2006.12.011

Cooper, S. (1996). Corporate Social Performance: A Stakeholder Approach, Ashgate Publishing: London

Cooper, S. (1996). Corporate Social Performance: A Stakeholder Approach, Ashgate Publishing: London

Cooper. (1996). Corporate Social Performance: A Stakeholder Approach, Ashgate Publishing: London. https://doi.org/10.4324/9781315259239

Corbetta \& Salvato. (2004). Self-Serving or Self-Actualizing? Models of Man and Agency Costs in Different Types of Family Firms: A Commentary on "Comparing the Agency Costs of Family and Non-Family Firms: Conceptual Issues and Exploratory Evidence" Entrepreneurship theory and practice, 28(4), 355-362. https://doi.org/10.1111/j.15406520.2004.00050.x

Corbetta \& Salvato. (2004). The Board of Directors in Family Firms: One Size Fits All?. Family Business Review, 17(2), 119-134. https://doi.org/10.1111/j.1741-6248.2004.00008.x

Cruz, Gómez-Mejía \& Becerra. (2010). Perceptions of Benevolence and the Design of Agency Contracts: CEO-TMT Relationships in Family Firms. Academy of Management Journal, 53(1), 
69-89. https://doi.org/10.5465/amj.2010.48036975

Dahawy \& Samaha (2010), An Investigation of the Views and Perceptions of External Users of Corporate Annual Reports in Emerging Economies: The Case of Egypt. International Journal of Accounting and Finance, 2(3-4), 331-367. https://doi.org/10.1504/IJAF.2010.034402

Dahawy. (2009). Developing Nations and Corporate Governance: The Story of Egypt. In The Global Corporate Governance Forum, The International Financial Corporation

Davis, Allen \& Hayes (2010), Is Blood Thicker Than Water? A Study of Stewardship Perceptions in Family Business. Entrepreneurship: Theory \& Practice, 34, 1093-1116. https://doi.org/10.1111/j.1540-6520.2010.00415.x

Davis, Schoorman \& Donaldso. (1997). Toward a Stewardship Theory of Management. Academy of Management Review, 22(1), 20-47. https://journals.aom.org/doi/abs/10.5465/amr.1997.9707180258

Donaldson \& Davis. (1991). Stewardship Theory or Agency Theory: CEO Governance and Shareholder Returns. Australian Journal of Management, 16(1), 49-64 https://journals.sagepub.com/doi/pdf/10.1177/031289629101600103?casa_token=gcyLess4a5 4AAAAA:WgO-g5hgghHyRwmtN8i618SPUlu2g1QYb0iQEkT_jB-srQAZlBiXFs4Ny17jdNhkFxU4o_1XZLq

Eisenhardt. (1989). Agency Theory: An Assessment and Review. Academy of Management Review, 14(1), 57-74. https://doi.org/10.5465/AMR.1989.4279003

El-Ansary \& Atuea. (2012). The Effect of Stock Trading Volume on Return in the Egyptian Stock Market. International Research Journal of Finance and Economics, ISSN 1450- 2887 Issue 100, 152-167.

El-Basuon. (2020). Effect of COVID-19 on the Arab Financial Markets Evidence From Egypt and KSA. IOSR Journal of Business and Management, 22(6), 14-21.

Elena. (2007). Corporate Governance: Shareholder's Interests and Other Stakeholders' Interest. Corporate Ownership and Control, 4(4), 96-102. https://doi.org/10.2139/ssrn.2302532

Elsayed \& Elrhim. (2020). The Effect of COVID-19 Spread on Egyptian Stock Market Sectors. Available at SSRN 3608734. https://doi.org/10.2139/ssrn.3608734

Freeman, Harrison,Wicks, Parmar \& De Colle. (2010). Stakeholder Theory: The State of The Art. Cambridge University Press. https://doi.org/10.5465/19416520.2010.495581

Gioia. (1999). Practicability, Paradigms, and Problems in Stakeholder Theorizing. Academy of Management Review, 24(2), 228-232. https://doi.org/10.5465/amr.1999.1893931

Handayani. (2018). Effect of Financial Performance on Share Price on Listed Companies in Indonesia Stock Exchange. In PROCEEDING ICTESS (Internasional Conference on Technology, Education and Social Sciences). 
Hernandez. (2008). Promoting Stewardship Behavior in Organizations: A Leadership Model. Journal of Business Ethics., 80, 121-128. https://doi.org/10.1007/s10551-007-9440-2

Ichsani \& Suhardi. (2015). The Effect of Return on Equity (ROE) and Return on Investment (ROI) on Trading Volume. Procedia-Social and Behavioral Sciences, 211, 896-902. https://doi.org/10.1016/j.sbspro.2015.11.118

Jensen \& Meckling. (1976). Theory of The Firm: Managerial Behavior, Agency Costs and Ownership Structure. Journal of Financial Economics, 3(4), 305-360. https://doi.org/10.1016/0304-405X(76)90026-X

Joher \& Ali. (2005). Corporate Governance Structure and Firm Performance: Empirical Evidence from Brusa Malaysia, Kuala Lumpur. International Business \& Economics Research Journal (IBER), 4(9). https://doi.org/10.19030/iber.v4i9.3620

Kaplan \& Norton. (1992). The Balanced Scorecard: Measures that Drive Performance.Harvard Business Review, 71-79.

Kultys. (2016). Controversies about Agency Theory as Theoretical Basis for Corporate Governance. Oeconomia Copernicana, 7(4), https://doi.org/10.12775/OeC.2016.034

Madison, Holt, Kellermanns \& Ranft. (2016). Viewing Family Firm Behavior and Governance Through the Lens of Agency and Stewardship Theories. Family Business Review, 29(1), 65-93. https://doi.org/10.1177/0894486515594292

Mahoney. (2012). Towards a Stakeholder Theory of Strategic Management. Towards A New Theory of the Firm. Barcelona: IESE Research Unit, forthcoming, 110. https://citeseerx.ist.psu.edu/viewdoc/download?doi=10.1.1.559.7962\&rep=rep1\&type=pdf

Nassirzadeh, Salehi \& Sarvghadi. (2015). The Effect of Financial Indicators on Trading Volume of the Listed Companies on the Tehran Stock Exchange. International Business Research, 8(5), 176. https://doi.org/10.5539/ibr.v8n5p176

Oluwatoyin \& Gbadebo. (2009). The Impact of Share Market Capitalization on a Company's Performance: A Case Study in The Nigerian Confectionary Industry. African Journal of Business Management, 3(5), 220.

García Padrón, Y., María Cáceres Apolinario, R., Maroto Santana, O., Concepción Verona Martel, M. and Jordán Sales, L. (2005). Determinant factors of leverage: An empirical analysis of Spanish corporations. Journal of Risk Finance, 6(1), 60-68. https://doi.org/10.1108/15265940510581279

Purnamawati. (2016). The Effect of Capital Structure and Profitability on Stock Price (Study of the Manufacturing Sector in Indonesia Stock Exchange). International Journal of Business, Economics and Law, 9(1), 10-16.

Rampling. (2012). From Agency to Stakeholder Theory: Realigning Executives Focus. Available at SSRN 2131096. https://doi.org/10.2139/ssrn.2131096

Ross. (1973). The Economic Theory of Agency: The Principal's Problem. The American 
Economic Review, 63(2), 134-139.

Samaha, K., Dahawy, K., Hussainey, K., \& Stapleton, P. (2012). The Extent of Corporate Governance Disclosure and Its Determinants in a Developing Market: The Case of Egypt. Advances in Accounting, 28(1), 168-178. https://doi.org/10.1016/j.adiac.2011.12.001

Schmitt \& Yu. (2001). Economies of Scale and the Volume of Intra-Industry Trade. Economics Letters, $74(1)$,

127-132. https://citeseerx.ist.psu.edu/viewdoc/download?doi=10.1.1.441.1888\&rep=rep1\&type=pdf

Senger (2011), The Relationship Between the Trading Volume and the Stock Returns in Small and Medium-Sized Enterprises in Egypt Nile Stock Exchange. Available at SSRN 2718845.

https://doi.org/10.2139/ssrn.2718845

Shawer \& Al-Ajlouni. (2018). Impact of Profitability on Stock Market Value: Evidence From Petrochemical Industry in Saudi Arabia. Journal of Administrative and Economic Sciences, Qassim University, 11(2), 23-47.

Teixeira. (2017). Stakeholder Theory vs Agency Theory in Portuguese NPO-an Endowment Approach.

Tosi, Brownlee, Silva \& Katz (2003), An Empirical Exploration of Decision-Making Under Agency Controls and Stewardship Structure. Journal of Management Studies, 40(8), 20532071. https://doi.org/10.1046/j.1467-6486.2003.00411.x

Wasserman. (2006). Stewards, Agents, and the Founder Discount: Executive Compensation in New Ventures. Academy of Management Journal, 49(5), 960-976. https://doi.org/10.5465/AMJ.2006.22798177

Wu, Chua \& Chrisman. (2007). Effects of Family Ownership and Management on Small Business Equity Financing. Journal of Business Venturing, 22(6), 875-895. https://doi.org/10.1016/j.jbusvent.2006.07.002

Zahra, Hayton, Neubaum, Dibrell \& Craig. (2008). Culture of Family Commitment and Strategic Flexibility: The Moderating Effect of Stewardship. Entrepreneurship Theory and Practice, 32(6), 1035-1054. https://doi.org/10.1111/j.1540-6520.2008.00271.x

Zahra, Gedajlovic, Neubaum \& Shulman. (2009). A Typology of Social Entrepreneurs: Motives, Search Processes and Ethical Challenges. Journal of Business Venturing, 24(5), 519-532. https://doi.org/10.1016/j.jbusvent.2008.04.007

Zaigham, Wang \& Ali. (2019). Causal Relation Between Stock Market Performance and Firm Investment in China: Mediating Role of Information Asymmetry. SAGE Open, 9(4), 2158244019885146. https://doi.org/10.1177/2158244019885146 